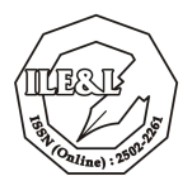

Journal Indonesian Language Education and Literature Vol. 2, No. 2, 2017 http://www.syekhnurjati.ac.id/jurnal/index.php/jeill/

\title{
PEMBELAJARAN MENULIS ESAI \\ MENGGUNAKAN MODEL COOPERATIVE INTEGRATED READING AND COMPOSITION (CIRC) BERBASIS LIFE SKILLS
}

\author{
Emah Khuzaemah dan Lilik Herawati \\ IAIN Syekh Nurjati Cirebon \\ emah.kh69@gmail.com
}

\begin{abstract}
Abstrak
Rendahnya keterampilan menulis mahasiswa IAIN Syekh Nurjati Cirebon memerlukan penanganan yang serius. Sebagai calon guru, mahasiswa Jurusan Tadris Bahasa Indonesia (TBI) perlu memperoleh pembekalan kemampuan menulis yang baik. Pembelajaran berbasis life skills akan mengarahkan mahasiswa untuk terampil menyelesaikan permasalahan-permasalahan kehidupan yang semakin kompleks. Pemilihan Cooperative Integrated Reading and Composition (CIRC) didasarkan atas pertimbangan bahwa lahirnya sebuah gagasan memerlukan stimulus. Untuk itu, dilakukan penelitian tindakan kelas dengan tujuan untuk mengetahui peningkatan kemampuan menulis esai mahasiswa melalui penerapan model pembelajaran CIRC berbasis life skills. Penelitian ini dilakukan di Jurusan TBI semester 2, tahun akademik 2015/2016. Hasil penelitian menunjukkan bahwa kemampuan menulis mahasiswa mengalami peningkatan pada setiap siklusnya, baik dari aspek kemampuan dalam memilih tema, merumuskan judul, mengorganisasikan gagasan, menganalisis, maupun teknik penulisan. Dengan demikian, penerapan model CIRC efektif untuk diterapkan dalam pembelajaran menulis esai.
\end{abstract}

Kata Kunci: esai, menulis, model Cooperative Integrated Reading and Composition

\begin{abstract}
The low skill of writing IAIN student Syekh Nurjati Cirebon requires serious handling. As a prospective teacher, students of Tadris Bahasa Indonesia (TBI) need to obtain good writing skill. Life-based learning skills will lead students to skillfully solve complex life problems. The selection of Cooperative Integrated Reading and Composition (CIRC) is based on the consideration that the birth of an idea requires a stimulus. For that purpose, a classroom action research is conducted to know the improvement of students' essay writing skills through the application of CIRC learning model based on life skills. This research was conducted in Department of TBI semester 2, academic of 2015/2016. The results showed that students' writing ability improved in each cycle, either from the aspect of ability in choosing the theme, formulating the title, organizing ideas, analyzing, and writing techniques. Thus, the application of the CIRC model is effective to apply in essay writing.
\end{abstract}

Keywords: essay, writing, model Cooperative Integrated Reading and Composition 


\section{Journal Indonesian Language Education and Literature Vol. 2, No. 2, 2017 http://www.syekhnurjati.ac.id/jurnal/index.php/jeill/}

\section{A. Pendahuluan}

Rendahnya keterampilan menulis mahasiswa memerlukan penanganan yang serius dari berbagai pihak. Penelitian yang telah dilakukan Suwandi (2015: 2) menunjukkan bahwa kemampuan menulis mahasiswa masih rendah. Kemampuan menulis memang merupakan kemampuan berbahasa yang paling sulit. Bell dan Burnaby di dalam Nunan (1989: 36) menyatakan bahwa menulis merupakan aktivitas kognitif yang kompleks karena memerlukan kontrol sejumlah variabel secara simultan. Begitu pun menurut Tarigan (2008: 8-9), keterampilan menulis menuntut pengalaman, waktu, kesempatan, pelatihan keterampilan-keterampilan khusus dan pengajaran langsung menjadi seorang penulis. Sama halnya dengan pendapat di atas, Rachmawati (2014: 1) juga berpendapat bahwa dalam pembelajaran menulis puisi, cerpen, dan teks drama memerlukan proses dan tidak dapat dikuasai peserta didik dengan sendirinya.

Menulis termasuk salah satu aktivitas berbahasa yang bersifat produktif dan ekspresif. Pelajar pada umumnya menganggap bahwa menulis itu sangat sulit. Hal itu dikeluhkan oleh banyak siswa di pendidikan dasar dan menengah, mahasiswa di perguruan tinggi pun mengeluhkan sulitnya menulis. Akibat keluhan itu akhirnya menjadi opini umum, bahwa menulis itu sulit (Sukirman, 2013: 1). Untuk mengarahkan mahasiswa agar mampu menulis karya ilmiah, harus dilakukan secara bertahap. Menurut Alwasilah (2009: 23) melatih mahasiswa agar mampu menulis, sebaiknya dimulai dari menulis paragraf narasi. Ketika para pelajar sudah mampu menulis narasi, secara bertahap mereka diarahkan untuk dapat menulis jenis paragraf yang lain, seperti eksposisi dan argumentasi. Hasil survei di beberapa jurusan, kemampuan mahasiswa semester satu dalam menulis narasi sudah cukup baik. Untuk itu, tahap berikutnya mahasiswa perlu dilatih untuk dapat menulis esai.

Kemampuan mahasiswa dalam menulis esai diharapkan dapat membantu dan memudahkan mahasiswa dalam menulis karya ilmiah. Esai didefinisikan sebagai sebuah karangan singkat yang berisi pendapat atau argumen penulis tentang suatu topik. Biasanya, seseorang menulis esai karena ia ingin memberikan pendapat terhadap suatu persoalan atau fenomena yang terjadi dalam masyarakat. Penulis esai, atau sering disebut esais, dapat juga mengupas suatu topik atau persoalan dan memberikan tanggapan dan pendapatnya atas topik atau persoalan yang dibahasnya. 
Esai merupakan buah pikir yang ditulis secara ringkas. Topik apa pun dapat ditulis dalam bentuk esai. Menurut Kamus Besar Bahasa Indonesia (KBBI) dijelaskan bahwa esai adalah "karangan prosa yang membahas suatu masalah secara sepintas lalu berdasarkan sudut pandang pribadi penulisnya" (Depdikbud, 1995: 270). Esai adalah "sepotong tulisan atau karangan pendek berbentuk prosa tentang suatu masalah" Menurut Procter $(E d)$, (dalam Budiyono, 2012: 20-21). Tulisan esai merupakan bentuk tulisan yang mengungkapkan persoalan yang terdapat di dalamnya sebatas ketertarikan penulisnya mengenai persoalan tersebut (Djuharie dan Suherli, 2001: 49). Berdasarkan pernyataan tersebut, bahasan pada suatu tulisan esai tidak begitu mendalam. Esai merupakan bagian (sepotong) dari sebuah tulisan, tetapi dapat juga esai diartikan sebagai sebuah karangan pendek yang utuh. Oleh karena itu, esai menjadi salah satu jenis tulisan yang sering dijadikan alat uji untuk mengukur intelegensi seseorang. Seorang yang berpengetahuan luas akan dapat menyampaikan gagasannya secara runtut, logis, dan menarik. Semakin sering seseorang membaca, semakin besar kemungkinan untuk dapat menulis esai dengan baik. Dengan banyak membaca, akan memiliki lebih banyak gagasan untuk ditulis. Persoalan utamanya tinggal mewujudkan gagasan yang sudah tertanam dalam pemikiran melalui tulisan yang harus terus-menerus berlatih agar semakin lama semakin sempurna.

Dengan berbasis life skills akan mengarahkan mahasiswa untuk terampil menyelesaikan permasalahan-permasalahan kehidupan yang semakin kompleks. Dalam memasuki era global, dunia pendidikan di Indonesia menghadapi tiga tantangan yang besar; Pertama, sebagai akibat krisis ekonomi, dunia pendidikan dituntut untuk dapat mempertahankan hasil-hasil pembangunan pendidikan yang telah dicapai. Kedua, untuk mengantisipasi efek globalisasi, dunia pendidikan dituntut untuk mempersiapkan SDM yang kompeten agar mampu bersaing dengan pasar kerja global. Ketiga, sejalan dengan diberlakukannya otonomi daerah, perlu dilakukan perubahan dan penyesuaian sistem pendidikan nasional sehingga dapat mewujudkan proses pendidikan yang lebih demokratis, memperhatikan keragaman kebutuhan/keadaan daerah dan siswa, serta mendorong partisipasi masyarakat.

Dalam penerapannya di bidang pendidikan, life skill sangat diperlukan oleh pengajar guna berkomunikasi dengan siswa di lingkungan akademik. Life skill dapat membantu seorang pengajar untuk menyampaikan isi materi secara lebih mendalam dan 
menyeluruh sehingga siswa dapat lebih mudah memahami materi. Tidak hanya itu, pendidikan life skill harus diajarkan kepada siswa sebagai bekal untuk hidup mandiri kelak. Seorang pendidik sudah selayaknya dituntut untuk dapat membekalkan nilai-nilai life skill kepada siswa. Dengan demikian pendidikan life skill harus dapat merefleksikan kehidupan nyata dalam proses pembelajaran agar peserta didik memperoleh kecakapan hidup tersebut, sehingga peserta didik siap untuk hidup di tengah-tengah masyarakat (Wahab, 2012: 218). Untuk itu, mahasiswa sebagai calon pendidik sangat penting memahami life skill dengan baik.

Sementara itu, pengembangan pembelajaran model kooperatif berpijak pada beberapa pendekatan yang diasumsikan mampu meningkatkan proses dan hasil belajar mahasiswa. Pendekatan yang dimaksud adalah belajar aktif, konstruktivistik, dan kooperatif. Beberapa pendekatan tersebut diintegrasikan dimaksudkan untuk menghasilkan suatu model pembelajaran yang memungkinkan mahasiswa dapat mengembangkan potensinya secara optimal. Agar mahasiswa memiliki kecakapan hidup. Pembelajaran ditekankan pada pemanfaatan ilmu pengetahuan yang dipelajari untuk bekal mahasiswa mengenali dan mengatasi masalah kehidupan. Pembelajaran tidak sekedar mengenal, mengingat dan memahami ilmu pengetahuan, tetapi diarahkan untuk menciptakan sesuatu yang bermanfaat bagi kehidupan.

Ada pun tipe kooperatif yang dipilih yaitu Cooperative Integrated Reading and Composition (CIRC) didasarkan atas pertimbangan bahwa lahirnya sebuah gagasan memerlukan stimulus. Salah satu stimulus yang efektif untuk dapat melahirkan ide baru adalah melalui membaca. CIRC berbasis life skill yang dimaksud di sini adalah teks yang dipilih sebagai stimulus mahasiswa dalam menulis esai adalah teks yang bertemakan persoalan-persoalan kehidupan yang memerlukan solusi atau penyelesaian, misalnya persoalan remaja, pendidikan, lingkungan, dan kemasyarakatan.

Widiati (2008: 187) menegaskan bahwa rendahnya kemampuan menulis mahasiswa disebabkan oleh minimnya aktivitas mahasiswa dalam membaca. Oleh karena itu, menurutnya untuk meningkatkan kemampuan menulis mahasiswa harus diikuti pembelajaran membaca. Membaca dan menulis secara terpadu dapat membantu mahasiswa dalam meningkatkan kemampuan menulisnya. Menurut Butler \& Turbill dalam Widiati (2008: 187), melalui kegiatan membacalah, para penulis belajar berbagai teknik menulis. 


\section{Journal Indonesian Language Education and Literature Vol. 2, No. 2, 2017 http://www.syekhnurjati.ac.id/jurnal/index.php/jeill/}

Suyono dalam Widiati (2008: 187-188) juga menegaskan bahwa pengalaman membaca-menulis dapat saling memengaruhi dan mendukung perkembangan kemampuan individu dalam membaca, menulis, dan berpikir sehingga pengalaman membaca-menulis tersebut akan memperkuat kemampuan penulis untuk membaca dan kemampuan pembaca untuk menulis. Untuk meningkatkan kemampuan membaca dan menulis siswa, dibutuhkan integrasi pengajaran kemampuan membaca dan menulis, yakni melalui kegiatan menggali dan memperluas pemahaman teks untuk mengembangkan kemampuan menulis.

Dengan demikian pilihan model Cooperative Integrated Reading and Composition berbasis life skills ini sangat tepat diterapkan dalam membina kemampuan mahasiswa dalam menulis esai agar mereka menjadi generasi yang peduli terhadap persoalan-persoalan kehidupan, memiliki kecakapan yang baik dan dapat menuangkan gagasan serta pemikirannya secara sistematis dalam bentuk tulisan.

\section{B. Metode Penelitian}

Metode yang digunakan dalam penelitian ini adalah penelitian tindakan kelas. Penelitian tindakan kelas dalam bahasa Inggris disebut dengan istilah classroom action research. Dari nama tersebut terkandung tiga kata yakni: penelitian, tindakan, dan kelas. Menurut Wardhani, dkk (2008: 14) penelitian tindakan kelas adalah penelitian yang dilakukan oleh dosen dalam kelasnya sendiri melalui refleksi diri dengan tujuan untuk memperbaiki kinerjanya sebagai seorang dosen, sehingga hasil belajar siswa menjadi meningkat. Sesuai dengan jenis penelitian yang akan dilakukan adalah suatu bentuk proses pengkajian berdaur siklus yang terdiri dari empat tahapan dasar yang saling terkait dan berkesinambungan, yaitu 1) perencanaan (planning), 2) pelaksanaan (acting), pengamatan (observing), 4) refleksi (reflecting).

Berdasarkan hasil tes kemampuan menulis mahasiswa, sebesar $60 \%$ mahasiswa sudah mampu menulis karangan narasi dengan baik. Artinya, mereka sudah mampu menuliskan cerita pengalaman pribadi secara runtut, paragrafnya cukup baik, struktur kalimatnya tepat, dan sedikit kesalahan EYD. Namun, ketika mereka diminta untuk menulis artikel populer, hanya $20 \%$ yang mampu mengembangkan paragraf dengan bahasa dan pilihan kata yang menarik, serta struktur kalimat yang tepat. Untuk itu, diperlukan sebuah teknik yang menarik yang mampu memotivasi mahasiswa agar dapat 
mengembangkan kemampuan menulisnya. Dengan demikian dilakukan penelitian tindakan kelas untuk mengetahui perkembangan/peningkatan dan perbaikan kemampuan mahasiswa dalam menulis karangan yang berupa esai. Dalam hal ini, peneliti akan menerapkan Model Pembelajaran Cooperative Integrated Reading and Composition (CIRC) Berbasis Life Skills.

Adapun untuk menganalisis kemampuan menulis esai mahasiswa, diukur melalui rubrik penilaian karya tulis mahasiswa yang dilihat dari unsur: substansi isi, struktur, pilihan kata, pengembangan paragraf, dan mekanik penulisan. Menganalisis data harus dilakukan dengan sungguh-sungguh, terstruktur, dan sistematis agar hasil yang didapat objektif. Rubrik untuk menilai kemampuan menulis esai mahasiswa adalah sebagai berikut.

Tabel 1. Rubrik Penilaian Kemampuan Mahasiswa dalam Menulis Esai

\begin{tabular}{llc}
\hline No & \multicolumn{1}{c}{ Aspek Penilaian } & Bobot Nilai \\
\hline 1 & $\begin{array}{l}\text { Kesesuaian Tema (topik yang ditulis sesuai dengan tema } \\
\text { esai yang telah ditentukan) }\end{array}$ & $10 \%$ \\
2 & $\begin{array}{l}\text { Gagasan (bersifat orisinal: menyajikan gagasan yang relatif } \\
\text { baru dan unik; kreatif: menunjukkan pemahaman baru atas } \\
\text { persoalan yang dibahas; aktual: gagasan sesuai dengan }\end{array}$ & \\
& $\begin{array}{l}\text { kondisi kekinian dengan menyajikan data dan fakta) } \\
\text { Argumentasi (sistematika gagasan runtut, tertib, dan jelas; } \\
\text { relevensi data dan informasi yang diacu dengan uraian } \\
\text { tulisan; kemampuan menganalisis \& sintesis serta } \\
\text { merumuskan simpulan) }\end{array}$ \\
& $\begin{array}{l}\text { Penulisan (tata tulis: kerapihan ketik, tata letak, dan jumlah } \\
\text { halaman; pengungkapan: sistematika tulisan, ketepatan dan } \\
\text { kejelasan ungkapan, bahasa baku yang baik dan benar, } \\
\text { komunikatif, dan relatif mudah dipahami) }\end{array}$ & \\
&
\end{tabular}

\section{Hasil dan Pembahasan}

Hasil penelitian ini meliputi desain model pembelajaran Cooperative Integrated Reading and Composition (CIRC) Berbasis Life Skills, deskripsi pelaksanaan pembelajaran, deskripsi peningkatan kemampuan menulis esai mahasiswa, dan deskripsi nilai-nilai life skills dalam tulisan mahasiswa.

Sebelum pelaksanaan pembelajaran di kelas, peneliti merencanakan pelaksanaan pembelajaran dengan menerapkan model Pembelajaran Cooperative Integrated Reading and Composition (CIRC). Agar pelaksanaan pembelajaran di kelas dapat dilaksanakan dengan baik dan terprogram, sebelumnya peneliti menyusun langkah- 
langkah desain pembelajaran Cooperative Integrated Reading and Composition (CIRC). Ada pun desain pembelajaran dalam penerapan Model Cooperative Integrated Reading and Composition (CIRC) Berbasis Life Skills diuraikan pada pemaparan berikut.

Tabel 2.

Desain Pembelajaran dalam penerapan Model Cooperative Integrated Reading and Composition (CIRC) Berbasis Life Skills

\begin{tabular}{|c|c|}
\hline $\begin{array}{l}\text { Fase-Fase } \\
\end{array}$ & Perilaku Dosen \\
\hline $\begin{array}{l}\text { Fase 1: Present goals and } \\
\text { set (Menyampaikan tujuan } \\
\text { dan memotivasi } \\
\text { mahasiswa) }\end{array}$ & $\begin{array}{l}\text { Dosen menyampaikan tujuan pembelajaran yang ingin } \\
\text { dicapai pada perkuliahan tersebut dan memotivasi } \\
\text { mahasiswa untuk banyak membaca dan menulis. } \\
\text { Sesuai dengan RPS yang sudah disusun, }\end{array}$ \\
\hline $\begin{array}{l}\text { Fase 2: Present } \\
\text { information }\end{array}$ & $\begin{array}{l}\text { Dosen menyampaikan informasi kepada mahasiswa } \\
\text { tentang membaca dan menulis }\end{array}$ \\
\hline Menyajikan informasi & $\begin{array}{l}\text { Memberikan beberapa contoh teks/ bacaan yang } \\
\text { bermuatan life skill. }\end{array}$ \\
\hline $\begin{array}{l}\text { Fase 3: Organize students } \\
\text { info learning teams }\end{array}$ & $\begin{array}{l}\text { Dosen menjelaskan kepada mahasiswa bagaimana } \\
\text { caranya membentuk kelompok belajar yang solid agar } \\
\text { melakukan transisi secara efisien dalam melakukan } \\
\text { aktivitas menulis untuk menghasilkan sebuah karya } \\
\text { tulis yang berkualitas }\end{array}$ \\
\hline $\begin{array}{l}\text { Fase 4: Assist team work } \\
\text { and study }\end{array}$ & $\begin{array}{l}\text { Dosen membimbing kelompok-kelompok belajar } \\
\text { mahasiswa pada saat mereka melakukan aktivitas } \\
\text { menulis. }\end{array}$ \\
\hline $\begin{array}{l}\text { Fase 5: Tes on the } \\
\text { materials } \\
\text { Evaluasi }\end{array}$ & $\begin{array}{l}\text { Dosen mengevaluasi hasil belajar tiap kelompok dan } \\
\text { menugaskan untuk mempresentasikan karya tulisnya }\end{array}$ \\
\hline $\begin{array}{l}\text { Fase 6: Provide } \\
\text { recognition } \\
\text { Memberikan penghargaan }\end{array}$ & $\begin{array}{l}\text { Dosen mencari cara untuk memberi penghargaan baik } \\
\text { upaya maupun hasil belajar individu dan kelompok. }\end{array}$ \\
\hline
\end{tabular}

Pelaksanaan pembelajaran melalui penerapan model Cooperative Integrated Reading and Composition (CIRC) Berbasis Life Skills ini dilakukan dalam dua siklus. Adapun penjelasan dari tahap-tahap desain pembelajaran model CIRC ini adalah sebagai berikut.

Fase 1: Present goals and set (Menyampaikan tujuan dan memotivasi mahasiswa), pada tahap ini, dosen menyampaikan tujuan pembelajaran menulis esai dan memotivasi mahasiswa agar rajin menulis dan menjadikan menulis sebagai kegiatan 
rutin mereka. Dosen juga menjelaskan apa manfaat dari menulis esai serta mengarahkan mahasiswa bagaimana agar memiliki keterampilan menulis yang baik. Bagaimana pun keterampilan menulis membutuhkan proses. Oleh karena itu, mahasiswa harus dimotivasi agar menyadari pentingnya memiliki keterampilan menulis yang baik.

Fase 2: Present Information (Menyampaikan informasi), pada tahap ini dosen menyampaikan informasi tentang teori menulis esai. Bagaimana agar mahasiswa mampu menulis esai yang baik, kriteria penulisan esai, memilih tema yang menarik, membuat judul esai yang menarik, serta mengembangkan sebuah tulisan esai. Pada tahap ini, dosen juga menyajikan contoh-contoh esai yang dapat menggugah dan menyadarkan siswa untuk memiliki kemampuan dan keterampilan yang baik dalam menjalani kehidupan agar tidak menjadi manusia yang tertinggal zaman. Melalui penyajian esai yang diberikan dosen, mahasiswa dapat menjadikan contoh esai tersebut sebagai model sehingga mereka memiliki gambaran tentang contoh tulisan esai yang baik. Selain itu, contoh model itu dapat juga sebagai stimulus bagi mahasiswa agar mereka terpancing untuk mendapatkan ide dari bahan yang dibacanya.

Fase 3: Organize students info learning teams (Mengorganisasikan mahasiswa ke dalam kelompok kooperatif), pada tahap ini mahasiswa dibagi menjadi beberapa kelompok kecil yang beranggotakan 4-5 orang. Mereka bekerja secara berkelompok untuk menulis esai. Dalam hal ini mahasiswa diberi kebebasan untuk memilih tema sesuai dengan kesepakatan kelompok. Setelah mahasiswa sepakat untuk memilih tema tertentu, mereka berdiskusi untuk menyusun kerangka esai yang akan mereka kembangkan. Berdasarkan kerangka yang sudah dibuat, mereka membagi materi atau sub judul dari esai tersebut. Jadi, dalam kerja kelompok ini, ada aktivitas menulis individual. Dari hasil penulisan secara individu ini, kemudian mereka kembali berdiskusi kelompok untuk menyatukan dan menyelaraskan beberapa tulisan ke dalam satu tulisan. Dalam kelompok mereka harus ada tim editor yang mengedit tulisan esai yang ditulis kelompok itu.

Fase 4: Assist team work and study (Membimbing kelompok bekerja dan belajar), pada saat mahasiswa melakukan diskusi kelompok, dosen harus membimbing dan memonitoring pelaksanaan kerja kelompok mahasiswa. Hal ini dilakukan agar mahasiswa dapat bekerja secara optimal. Meskipun mahasiswa sudah dewasa dan mampu bersikap serta aktif dalam proses diskusi, dosen tetap harus membimbing 
mereka untuk dapat memberikan pengarahan dan penjelasan apabila terdapat hal-hal yang dipertanyakan mahasiswa. Pada tahap ini mahasiswa melakukan kerja kelompok untuk sharing penyusunan esai, baik dari sisi tema, kerangka, ataupun pengembangan substansi penulisan.

Fase 5: Tes on the materials (Evaluasi), pelaksanaan evaluasi terhadap hasil penulisan esai ini dilakukan melalui proses dan hasil karya esai mahasiswa. Evaluasi proses dilakukan melalui pengamatan terhadap aktivitas mahasiswa dalam melakukan kerja kelompok dan dalam mengembangkan tulisan. Proses menulis dari awal pemilihan tema, perumusan kerangka hingga ke pengembangan kerangka, dan akhirnya mempresentasikan hasil kerjanya. Semua dinilai dan diamati. Adapun hasil tertulis karya esai mahasiswa juga dinilai dan dievaluasi berdasarkan rubrik penilaian yang telah disusun sebelumnya.

Fase 6: Provide recognition (Memberikan penghargaan) Ketika mahasiswa mempresentasikan hasil kerja kelompoknya, kelompok yang lain juga mengamati, mengomentari, dan memberikan masukan. Selain itu juga dibuat tim khusus yang bersifat independen untuk menilai penampilan pembacaan karya esai mahasiswa. Karya terbaik yang dipresentasikan itu akan mendapatkan penghargaan dari dosen berdasarkan penilaian dosen dan tim penilai yang sudah ditunjuk oleh dosen.

Deskripsi kemampuan mahasiswa dalam menulis esai, dianalisis sesuai dengan rubrik penilaian yang digunakan peneliti untuk menganalisis kemampuan mahasiswa dalam menulis esai, yang meliputi: kemampuan mahasiswa dalam memilih tema dan merumuskan judul, kemampuan mahasiswa dalam mengorganisasikan gagasan, kemampuan mahasiswa dalam menganalisis dan menyintesis permasalahan, dan kemampuan mahasiswa dalam menerapkan EYD serta mekamik penulisan. Kemampuan mahasiswa dari setiap siklusnya mengalami peningkatan. Pada bagian berikut dipaparkan kemampuan akhir mahasiswa setelah diterapkan model pembelajaran CIRC berbasis life skills dalam dua siklus

Kemampuan mahasiswa dalam memilih tema dan merumuskan judul pada siklus kedua mengalami peningkatan yang berarti. Tema-tema yang dipilih mahasiswa sudah cukup spesifik, bukan lagi tema-tema seperti siswa SMA. Mahasiswa pada umumnya sudah mampu memilih tema yang spesifik, tema yang mereka pilih juga cukup menarik dan sedang menjadi pembicaraaan hangat. Siswa sudah mampu memilih tema yang 
spesifik, begitu pun dengan rumusan judul yang mereka buat. Terdapat 28 dari 37 mahasiswa $(75,67 \%)$ sudah dapat memilih tema merumuskan judul yang menarik.

Alur penalaran dari penulisan yang dilakukan yang dilakukan mahasiswa pada siklus kedua ini mengalami peningkatan yang cukup baik. Mahasiswa sudah terbiasa untuk mengawali sebuah tulisan dengan menggunakan paragraf pengantar sebagai pendahuluan sebuah tulisan. Kemudian isi, yang menawarkan gagasan serta cara pemecahannya. Serta penutup, yang kemudian menyimpulkan isi dari suatu esai. Pengorganisasian yang ditulis mahasiswa sudah mulai teratur. Mereka sudah mampu menulis dengan organisasi tulisan yang baik, sehingga pada umumnya gagasan mahasiswa sudah terorganisasi dengan baik. Terdapat 22 mahasiswa atau 59,46 mahasiswa sudah mampu mengorganisasikan gagasan dengan baik. Selebihnya 15 mahasiswa dari 37 mahasiswa (40,54\%) yang belum mampu mengorganisasikan gagasan dengan baik. Hal ini tentunya masih membutuhkan pembinaan lebih lanjut. Namun mengingat keterbatasan waktu, pembinaannya dilanjutkan pada pembelajaran materi menulis berikutnya.

Pada siklus kedua ini mahasiswa mengalami perubahan yang baik, sebanyak 17 dari 37 mahasiswa $(45,95 \%)$ mampu menyusun perumusan masalah dengan benar. Masalah yang dikemukakannya tidak hanya sebatas gejala masalahnya. Masalah yang dikemukakan sudah didukung data-data valid yang menunjukkan bahwa masalah itu perlu ditangani segera walaupun masih belum maksimal. Selanjutnya kelayakan solusi yang diajukan juga sudah hampir jelas. Solusi yang diajukannya mulai terlihat bahwa bisa memecahkan masalah yang ada. Kemampuan mahasiswa dalam menganalisis dan mensintesis permasalahan pada siklus dua ini juga masih banyak terdapat kekurangan. Mereka masih perlu bimbingan dan perbaikan.

Kemampuan mekanik tulisan mahasiswa pada siklus kedua ini mengalami perubahan yang sangat baik. Hanya sedikit mahasiswa, 13,5\%, artinya 5 orang dari 37 mahasiswa yang masih membutuhkan perbaikan. Kemampuan tata tulis mereka dilihat dari kerapihan tata ketik, tata letak, hampir tidak terdapat kesalahan. Demikian juga dengan jumlah halaman yang mereka tulis sudah memadai. Terdapat $86,5 \%$ mahasiswa yang sudah baik dan rapih dari sisi mekanik penulisan serta sistematika tulisan. Baik dilihat dari ketepatan dan kejelasan ungkapan, bahasa baku yang baik dan benar, komunikatif, dan relatif mudah dipahami. 


\section{Journal Indonesian Language Education and Literature Vol. 2, No. 2, 2017 \\ http://www.syekhnurjati.ac.id/jurnal/index.php/jeill/}

Dari aspek mengorganisasi gagasan, meskipun belum maksimal, mahasiswa sudah dapat dikatakan mengalami peningkatan yang baik dibandingkan siklus sebelumnya. Begitu pun dengan kemampuan mahasiswa dalam menganalisis dan mensintesis permasalahan kemampuan mahasiswa masih memerlukan pembinaan lebih lanjut. Pembinaan mahasiswa dalam menganalisis dan mensintesis ini tetap dilakukan pada pembelajaran materi menulis selanjutnya. Perbandingan kemampuan mahasiswa dalam menulis esai pada siklus satu dan dua dapat dilihat pada gambar berikut.

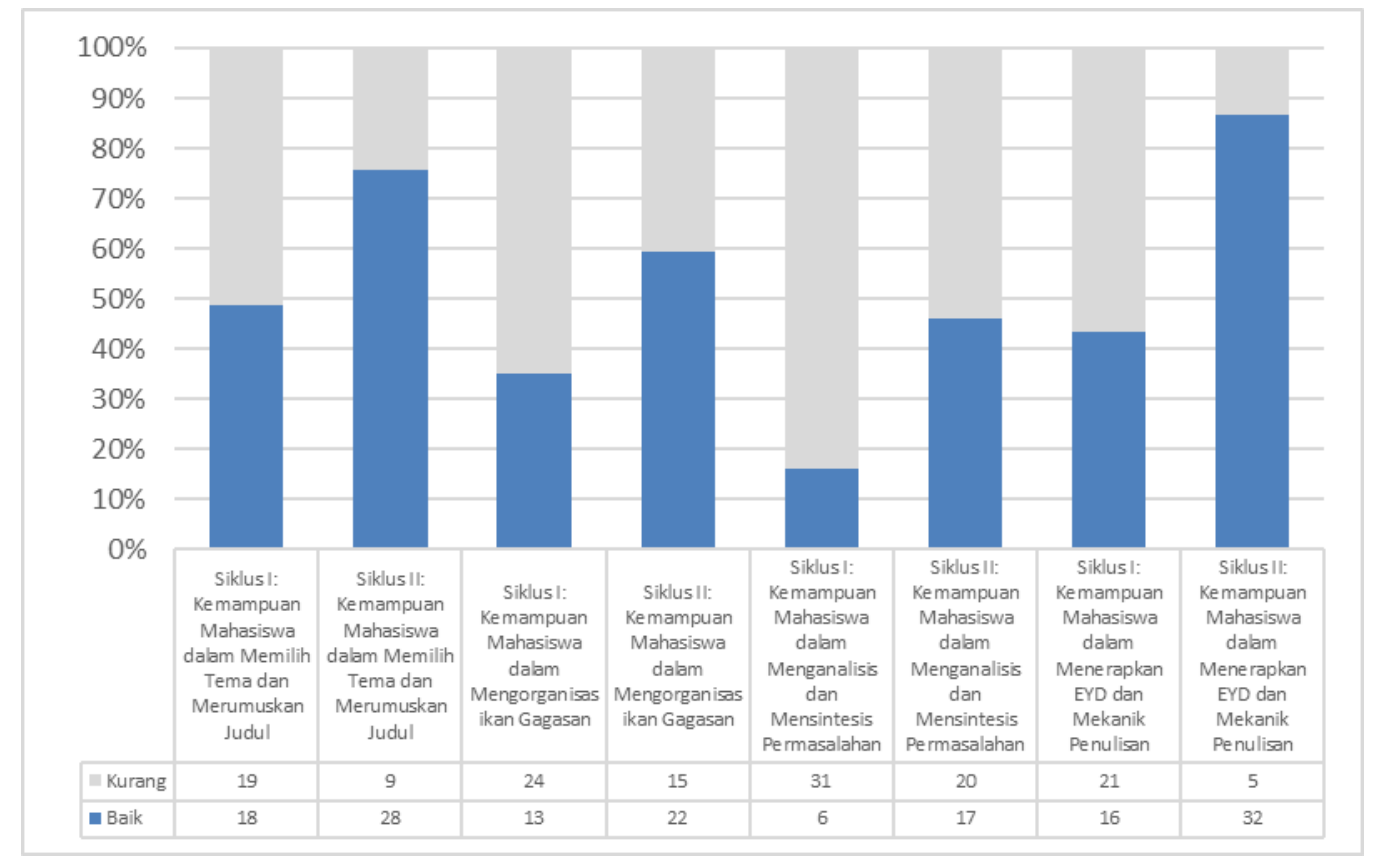

Gambar 1. Perbandingan Kemampuan Menulis Mahasiswa Pada Siklus 1 dan 2

Gambar di atas menunjukkan bahwa peningkatan tertinggi mahasiswa dalam menulis esai terdapat pada aspek mekanik penulisan. Hal ini dimungkinkan pada saat proses koreksi dan revisi dapat dilakukan mahasiswa lebih maksimal. Keadaan ini dapat dipahami bahwa sesungguhnya mahasiswa akan melakukan revisi secara maksimal apabila ada koreksi dari pihak dosen ataupun melalui saling koreksi oleh mahasiswa sendiri. Aspek analisis dan sintesis terlihat belum maksimal dikuasai oleh siswa, namun sesungguhnya bila dibandingkan kemampuan siklus sebelumnya, peningkatannya cukup tinggi. Pembinaan tetap dilakukan namun pada pembelajaran menulis materi selanjutnya.

Deskripsi nilai-nilai life skills pada tulisan mahasiswa ini hanya dianalisis pada tulisan akhir mahasiswa. Artinya, tulisan mahasiswa pada siklus pertama tidak dianalisis 
nilai-nilai life skills-nya. Dengan pertimbangan bahwa tulisan mereka masih memerlukan perbaikan, baik dari aspek konten maupun pengorganisasian dan mekanik penulisannya. Untuk itu, analisis nilai-nilai life skills dalam tulisan mahasiswa hanya dilakukan pada hasil tulisan mahasiswa siklus kedua.

Pada tulisan yang disusun mahasiswa sudah banyak terekspresikan nilai-nilai kecakapan hidup (life skills). Pada cuplikan karya Septiyani misalnya, mengandung kecakapan personal (personal skills) yang sekaligus juga mencakup kecakapan mengenal diri (self awareness) dan kecakapan berpikir rasional (thinking skills). Septiyani sudah memiliki kecakapan dalam menggali dan menemukan informasi (informating searching), kecakapan mengolah informasi dan mengambil keputusasn (informating processing and decision making skills), serta kecakapan memecahkan masalah secara kreatif (creative problem solving skills).

Kecakapan personal dalam mengenal diri sebagai hamba Allah juga terlihat pada tulisan-tulisan mahasiswa. Kecakapan mengenal diri pada dasarnya merupakan penghayatan diri sebagai makhluk Tuhan Yang Maha Esa, anggota masyarakat dan warga negara, serta menyadari dan mensyukuri kelebihan dan kekurangan yang dimiliki, sekaligus menjadikan sebagai modal dalam meningkatkan dirinya sebagai individu yang bermanfaat bagi dirinya sendiri dan lingkungannya.

Kecakapan sosial pada tulisan mahasiswa menunjukkan rasa perhatian dan empati yang sangat tinggi terhadap keadaan masyarakat Indonesia yang sudah mulai meninggalkan jati diri sebagai bangsa yang ramah, penuh rasa kebersamaan, dan saling menolong. Begitu pun cuplikan karya Ummi, Zahidin, dan Rostiyati memberikan perhatian terhadap keadaan masyarakat saat ini. Kondisi masyarakat yang sudah mulai memiliki budaya belanja online dan oknum-oknum yang memanfaatkan keadaan ini menjadi perhatian Hikmah pada tulisannya. Fenomena jual beli online yang terkadang merugikan konsumen. Begitu pun pada karya Zahidin, terlihat bahwa penulisnya memiliki empati yang tinggi terhadap keadaan masyarakat di dunia pertelevisian. Zahidin memberikan perhatian masyarakatnya yang terkadang dipermainkan oleh para elit politik yang memiliki kekuasaan untuk menyampaikan sesuatu yang menjadi kepentingannya melalui media yang sangat dekat dengan masyarakat, yaitu televisi.

Dari tulisan-tulisan mahasiswa, terkandung kecakapan sosial yang tinggi. Kecakapan sosial (social skills) meliputi kecakapan interpersonal (interpersonal skills) 
antara lain kecakapan komunikasi dengan empati (communication skills) dan kecakapan bekerjasama (colaboration skills). Dua kecakapan hidup di atas biasanya disebut sebagai kecakapan hidup bersifat umum atau general (general life skills).

Pada tulisan-tulisan mahasiswa juga terdapat kecakapanakademik yang merupakan aspek dari life skills. Pada tulisan Shofuroh dan Septiyani misalnya, terlihat kecakapan akademiknya yang sangat tinggi. Telah disadari bahwa seorang mahasiswa harus rajin membaca untuk memperluas wawasan dan mencintai ilmu. Hal ini dapat dilakukan dengan mengunjungi perpustakaan.

Demikian juga pada tulisan mahasiswa yang lain. Tulisan-tulisan mahasiswa juga terlihat mengandung nilai kecakapan vokasional. Mahasiswa sudah mampu menunjukkan bidang pekerjaan tertentu yang ada di tengah-tengah masyarakat, misalnya memaparkan salah satu bidang pekerjaan yang ada di masyarakat. Salah satu pekerjaan di bidang pertanian harus juga menjadi perhatikan pemerintah. Mahasiswa memaparkan bahwa sektor pertanian sangat potensial di Indonesia yang memiliki tanah yang subur ini. Tulisan ini menuturkan salah satu bidang kerja yang sesuai dengan keadaan alam Indonesia, yaitu sektor pertanian. Kecakapan vokasional (vocasional skills) sering kali disebut dengan kecakapan kejuruan. Artinya kecakapan yang dikaitkan dengan bidang pekerjaan tertentu yang terdapat di masyarakat.

Dari tulisan-tulisan mahasiswa, dapat diketahui bahwa nilai-nilai life skill yang diekspresikan mahasiswa melalui esai, sudah cukup baik. Kesadaran mahasiswa terhadap nilai-nilai kehidupan yang patut dimiliki sudah terlihat. Mahasiswa terlihat sudah menyadari bahwa dalam menjalani kehidupan ini. Artinya, seseorang harus memiliki kecakapan hidup, agar dapat menjalankan perannya sebagai khalifah di muka bumi ini dengan sebaik-baiknya. Kesadaran mahasiswa terhadap nilai-nilai life skill ini dapat dikembangkan dan dibina secara berkelanjutan agar pemahamannya terhadap makna hidup ini semakin jelas.

\section{Simpulan}

Berdasarkan analisis penerapan model pembelajaran Cooperative Integrated Reading and Composition (CIRC) sangat efektif untuk diterapkan dalam pembelajaran menulis.yang sudah dilakukan. Kemampuan mahasiswa dalam menulis esai setelah diterapkan model Cooperative Integrated Reading and Composition (CIRC) berbasis 
life skills dalam pembelajaran Bahasa Indonesia di FITK mengalami peningkatan dari setiap siklusnya. Deskripsi kemampuan mahasiswa dalam menulis esai pada setiap siklus dianalisis sesuai dengan rubrik penilaian yang digunakan peneliti untuk menganalisis kemampuan mahasiswa dalam menulis esai. Kemampuan menulis mahasiswa pada siklus dua mengalami peningkatan, baik dari aspek kemampuan mahasiswa dalam memilih tema dan merumuskan judul, kemampuan mahasiswa dalam mengorganisasikan gagasan, kemampuan mahasiswa dalam menganalisis dan mensintesis permasalahan, maupun kemampuan mahasiswa dalam menerapkan EYD serta mekanik penulisan.Kemampuan mahasiswa dalam menganalisis dan mensintesis permasalahan meskipun ada peningkatan, kemampuan mereka masih belum maksimal. Penelitian tindakan ini diakhiri mengingat keterbatasan waktu. Pembinaan mahasiswa dalam aspek argumentasi ini tetap dilakukan pada pembelajaran materi berikutnya.

\section{Daftar Pustaka}

Alwasilah, A. Chaedar. 2009. Pokoknya Menulis. Bandung: Angkasa.

Budiyono, Herman. 2012. "Mengembangkan Paragraf Sesuai Fungsi dan Posisi dalam Rangka Menulis Sebuah Tulisan Esai"dalam Jurnal Pena, Vol. 2, No. 2, Juli.

Depdikbud. 1995. Kamus Besar Bahasa Indonesia (KBBI). Jakarta: Balai Pustaka.

Djuharie, O.S. dan Suherli. 2001. Panduan Membuat Karya Tulis: Resensi, Laporan Buku, Skripsi, Tesis, Artikel, Makalah, Berita, Essei, dll. Bandung: Yrama Widya.

Nunan, David. 1989. Designing Tasks for the Communicative Classroom. Cambridge: Cambridge University Press.

Rachmawati, Dea Triani. 2014. Penerapan Metode Menulis Berantai dalam Meningkatkan Kemampuan Menulis Cerpen. Universitas Pendidikan Indonesia .

Sukirman, Dio Syukur. 2013. Pembelajaran Menulis Laporan Perjalanan dengan Menggunakan Pendekatan Kontekstual pada Siswa Kelas VIII. Bandung: STKIP Siliwangi.

Suwandi, Sarwiji. 2015. "Peran Bahasa Indonesia dalam Pengembangan Budaya Literasi untuk Mewujudkan Bangsa yang Unggul dalam Konteks Masyarakat Ekonomi Asean". Seminar Nasional dengan tema "Peran Bahasa dan Sastra Indonesia dalam Menghadapi Masyarakat Ekonomi Asean (MEA)" yang diselenggarakan STKIP Siliwangi Bandung, 25 November 2015. Prosiding Seminar Nasional Pendidikan Bahasa dan Sastra Indonesia. 
Tarigan, Hendry Guntur. 2008. Menulis Sebagai Suatu Keterampilan Berbahasa. Bandung: Angkasa.

Wahab, Rohmalina. 2012. "Reformulasi Inovasi Kurikulum: Kajian Life Skill untuk Mengantarkan Peserta Didik Menjadi Warga Negara yang Sukses" dalam $T A$ 'DIB, Vol. XVII, No. 02, Edisi Desember 2012.

Widiati, Utami. 2008. Pembelajaran Membaca-Menulis Terpadu Melalui Buddy Journals untuk Meningkatkan Kemampuan Menulis Mahasiswa Jurusan Sastra Inggris dalam BAHASA DAN SENI, Tahun 36, Nomor 2, Agustus 2008. 